\title{
Evaluating some Quality Parameters of a Surface Water Source by Applying Simple Treatment Processes
}

\author{
Cristina EL MAHDY' ${ }^{1}$, Silvana POPESCU², Blaga Petrean Anamaria ${ }^{2}$, Cristin BORDA ${ }^{2}$ \\ ${ }^{1}$ Department of Fundamental Sciences, Faculty of Animal Science and Biotechnologies, University of \\ Agricultural Sciences and Veterinary Medicine Cluj, România \\ ${ }^{2}$ Departament of Animal production and the food safety, Faculty of Veterinary Medicine, University of \\ Agricultural Sciences and Veterinary Medicine, Cluj, România \\ *corresponding author: silvana.popescu@usamvcluj.ro
}

Bulletin UASVM Animal Science and Biotechnologies 76(1)/ 2019

Print ISSN 1843-5262; Electronic ISSN 1843-536X

DOI:10.15835/buasvmcn-asb: 2018-0012

\begin{abstract}
The purpose of the research was to identify the most convenient treatment applied to a surface water source which is permanently under the influence of contamination, in order to reduce organic matter, temporary hardness and TNG/ml water. Following the sedimentation process, temporary hardness values are close to those of the control samples (raw water) but, reductions and extremely significant differences $(* * * \mathrm{P}<0.001)$ were found after coagulation. The same, extremely significant differences are found in the CCOMn parameter after the same process, coagulation. Applying just a single treatment like: sedimentation, coagulation of raw water without being followed by disinfection does not guarantee the removal or reduction of the total number of germs in water. Disinfection with UV dose (3.40-3.88 mj/cm2) of control samples indicates a significant reduction in bacterial load depending on exposure time, with the best values obtained at the 30 minute exposure. The same positive results were obtained from samples subjected to sedimentation where, compared to the initial values $(4159.2 \pm 1860.0 \mathrm{TNG} / \mathrm{ml}$ water), bacterial load is reduced by $78-99.82 \%$. In $60 \%$ of samples coagulated and after that exposed to 30 minutes of UV irradiation, was found $0 \mathrm{TNG} / \mathrm{ml}$ water. In conclusion, the best option for reducing TNG/ml water is coagulation using alum, followed by UV disinfection for 30 minutes.
\end{abstract}

Keywords: coagulation, TNG, sedimentation, ultraviolet, water

\section{Introduction}

After Bartram and Balance (1996), the water and in particular surface ones can suffer quality changes from minute to minute, from day to day, may have diurnal variations; is subject to contamination with irregular pollution sources including: fertilizers, pesticides and herbicides, and which, are moved along with alluviums from farmland or wastewater discharge coming from existing factories in the area.

One of the parameters which show the quality of water is: turbidity (Zahra et al., 2017). Turbidity of water vary daily, depending on the activities and conditions from upstream (Jowa and Mguni, 2015) and is often due to alluviums, particles of mineral origin such as clay, dust; natural organic matter, organic products of synthesis as well as inorganic materials such as: asbestos, silicate but also, radioactive particles (Dawson, 2018).

Small suspensions from the water have a negative charge and because they have the same type of load, they mutually reject when are approaching each other (Daryabeigi and Hoveidi, 2015). In addition, colloidal impurities in water 
shelter microorganisms, some of them pathogenic (Zahra et al., 2017). As a consequence of this fact, effective elimination of turbidity is necessary to ensure the removal of many contaminants that can be health disturbance factor. In addition, effective removal of turbidity can facilitate all other water treatment processes (Daryabeigi and Hoveidi 2015).

The organic substance present in water is a heterogeneous mixture of organic compounds resulting from contamination with animal and vegetal residues, household and industrial wastes (Zehra et al., 2009). The present of organic matter, adversely affects water quality, causing changes of: color, taste, smell, affects water treatment, application of disinfectants and biological stability (Lanciné et al., 2008). Natural water sources from: dams, rivers, wells and freshwater tanks can contain bacteria, viruses, parasites and algae that can cause illnesses or water diseases (Davis, 2016). Coagulation, flocculation, sedimentation, filtration and disinfection are the most common treatment processes widely used in the world (Baghvand et al., 2010), being effective and economic at the same time (Matilainen et al., 2010).

By sedimentation, sedimentary particles are deposited prior to filtration (Betancourt and Rose, 2004). But, colloidal particles and microorganisms, no, because have small size. Dependent on size, viruses $(0.01-0.1 \mu \mathrm{m})$ are the most difficult to remove from water by sedimentation and filtering (Gray, 2014). Bacteria, slightly larger in size $(0.5-1.0 \mu \mathrm{m})$ and protozoans $(5-100 \mu \mathrm{m})$ can be eliminated through sedimentation and filtration processes.

Coagulation is an important treatment step because turbidity is eliminated in a proportion of up to $99 \%$ (Taurai and Mguni, 2015), at present, being one of the most important physical-chemical operations used in water treatment, which is based among other sources, on adding of cationic coagulants whose positive electric charge results in destabilization of the particles and neutralizing the charge (Pernitsky and Edzwald, 2006).

The flocculation process offers the possibility that colloids with small size and negative charge (zeta potential) to gather together, to form larger aggregates, flocs, which deposit as sediment, improving the clarity of water by filtration (Mbaeze et al., 2017). In presents, coagulants based on alums are used not only to eliminate turbidity but also, to remove the dissolved substances (Kimura et al., 2013), color and microorganisms from water (Mouna and Noureddine, 2013).

The most common and economical water treatment solution is using as coagulating agent, aluminum sulphate commonly referred to as alum or aluminium sulphate $\left(\mathrm{Al}_{2}\left(\mathrm{SO}_{4}\right) \cdot \mathrm{nH} 2 \mathrm{O}\right)$ (Sahu and Chaudhari, 2013). The coagulation stage it is considered by Gwyn et al. (2014) " the heart of the water treatment process ".The processes of: coagulation, sedimentation, filtration, plays an important role in improving the water quality and the reduction of the bacterial load.

Processed data and the results obtained following the investigation of some data base and websites by Mann et al., (2007) highlighted that, the consumption of turbid water is associated with the installation of gastrointestinal diseases.

Through coagulation, the percentage of removal of turbidity and organic matter is up to 70\% (Moșneag, and Popescu, 2011). The value of turbidity, can be reduced following the coagulation process using alum (Matilainen et al., 2005). In the world, are used numerous methods of coagulation and sedimentation making it difficult comparing data, but Stanfield et al. (2003), specifies that, through the two methods is removed between 44 and $99 \%$ of the bacteria. In a larger study conducted by Bulson et al. (1984) performed both in under laboratory and field conditions, which had as their central point removal of phosphorus from a eutrophic recreational lake, they highlighted the fact that: following treatment with alum, within 72 hours, fecal coliforms from water have been removed in a proportion of $90 \%$ and $70 \%$ fecal streptococci.

The disinfection is destined to inactivate the viability/theinfectiouscapacityofmicroorganisms, either by using chemical disinfectants of which, the most common is chlorine and chlorinated substances (Betancourt and Rose, 2004); either by UV application, in order to control microbial contamination (Zyara et al., 2016).

Inactivation of microorganisms such as $E$ Coli, indicator bacteria, by UV disinfection of water, depends on the solid suspension load. Some of these microorganisms can survive due to agglomeration or particle association that protects microorganisms (Guo, 2005). 
Liu and Zhang (2006), demonstrates the efficiency of using UV radiation as a way of inactivating microorganisms and concludes that, UV radiation can exceed the negative barrier of turbidity at the same UV dose but greater intensity, positively influencing the effect of inactivating microorganisms.

Testing the effectiveness of the inactivation of the heterotrophic bacteria under the action of UV radiation from two commercial recirculating aquaculture systems, one indoor system and one outdoor system performed by Gullian et al. (2011), revealed that the disinfection efficiency was $90 \%$ after 24 hours at turbidity values below 9.9 NTU in the indoor system and $89.8 \%$ below 8 NTU after 72 hours of the outdoor system. The conclusion of the authors was that, the elimination of heterotrophic bacteria at turbidities higher than 11 NTU is unlikely to be cost-effective.

The sensitivity of microorganisms to UV irradiation varies from one species to another, and much more, by the wavelength of the radiation (254-260 nm) (Johnson et al., 2010). UV efficacy against bacteria depends on UV Dose $\left(\mathrm{mJ} / \mathrm{cm}^{2}\right)$. From microorganisms that can be inactivated at UV dose $\left(1 \log -0.5 \mathrm{~mJ} / \mathrm{cm}^{2}-3.5 \log \mathrm{mJ} /\right.$ $\mathrm{cm}^{2}$ ) are: Aeromonas hydrophila, Campylobacter jejuni, Escherichia coli, Legionella pneumophila, Salmonella derby (3.5), Salmonella infantis, Salmonella typhi, Salmonella typhimurium, Shigella dysenteriae $\left(0.5 \mathrm{~mJ} / \mathrm{cm}^{2}\right)$, Cryptosporidium parvum oocysts.

Staphylococcus aureus $\left(3.9 \mathrm{~mJ} / \mathrm{cm}^{2}\right)$, Streptococcus faecalis $\left(6.6 \mathrm{~mJ} / \mathrm{cm}^{2}\right)$, Salmonella enteritidis $\left(5 \mathrm{~mJ} / \mathrm{cm}^{2}\right)$, Salmonella anatum $(7.5 \mathrm{~mJ} /$ $\left.\mathrm{cm}^{2}\right)$, Klebsiella terrigena $\left(4.6 \mathrm{~mJ} / \mathrm{cm}^{2}\right)$, Bacillus subtilis spores, Giardia lamblia cysts, Giardia muris cysts,are part of the group of resistant microorganisms that require higher UV Dose (mJ/ $\mathrm{cm}^{2}$ ) per log reduction (Chevrefils et al., 2006).

\section{Materials and Methods Collecting water samples}

Water samples were collected from a source of surface water (brook) located at latitude 46.74703935 and longitude 23.524306116446002, found in permanent change of parameters, especially in days with precipitation or snow melting. The climate in the area is temperate-continental, with slight oceanic influences. The average of annual temperature is
$8.2{ }^{\circ} \mathrm{C}$ and average of rainfall is $557 \mathrm{~mm}$ (https:// www.vremea.ro/). Collection of samples for physical-chemical analysis was performed in accordance with the sampling rules, using plastic bottles with a capacity of $2 \mathrm{l}$, and filled with water by inserting the bottle against the water stream. The samples did not require preservation or keeping at low temperatures, because, the time between the two actions: collection, analysis, did not exceed 30 minutes. For the bacteriological examination, were used sterile bottles with a capacity of $500 \mathrm{ml}$, filled up to $2 \mathrm{~cm}$ below cap, hermetically sealed (http://www.dspcluj.ro/).

The raw sample was analyzed by point of view of parameters: turbidity, $\mathrm{pH}$, temporary hardness, organic matter, TNG/ml water. In the second step, the raw sample was subjected to sedimentation and coagulation, following. In the second step, the raw sample was subjected to sedimentation and coagulation, following followed by the determination of the parameters specified in step 1. All samples (raw, after sedimentation, coagulation) were subjected to desinfection with UV. Exposure times were 10, 20, 30 minutes.

Turbidity was analyzed with portable turbidimeter ISO HI 98713 ( $\pm 2 \%$ accuracy), initial $\mathrm{pH}$ and after coagulation process, with portable pH ISO HI 98129 (accuracy \pm 0.01 unit pH). The sedimentation was done by the sedimentation method, leaving the sample in rest for 2 hours in the Imhoff cone, using the supernatant in research, the oxygen regime group attention was paid to analyzing the chemical oxygen demand (CCOMn, STAS 3002/85).

Dose of coagulant, aluminum sulphate (alum) used in coagulation, was obtained according to the method described by Man (1986), starting from the analysis of temporary hardness (the indicator solution of methylorange $1 \%$ and titration with $\mathrm{HCl}, \mathrm{n} / 10$ ) not after initial value of $\mathrm{pH}$. Depending on the obtained values, by jar test it was added the required amount of alum $\mathrm{Al}_{2}\left(\mathrm{SO}_{4}\right)_{3}$. Three Erlenmeyer glasses were used for each sample and in every Erlenmeyer glasses was added $200 \mathrm{ml}$ of water. In Erlenmeyer number 2, was added the amount of alum corresponding to the value obtained at the temporary hardness parameter.

In the first glass the amount of alum was introduced corresponding to degree of hardness lower by 1 and in the third glass, the quantity required for water with a higher degree 
Table 1. The value obtained at temporary hardness and organic matter in those three variants

\begin{tabular}{cccc}
\hline Temporary hardness $\left(\mathrm{Germany}^{0}\right)$ & mean $\pm \mathrm{Sd}$ & Sedimentation & Coagulation \\
\hline Raw water & $12.55 \pm 2.72$ & ns $\mathrm{P}>0.05$ & $* * * \mathrm{P}<0.001$ \\
\hline Sedimentation & $12.29 \pm 2.57$ & - & $* * * \mathrm{P}<0.001$ \\
\hline Coagulation & $3.84 \pm 0.87$ & - & - \\
\hline Organic matter CCOMn $\left(\mathrm{mgO}_{2}\right) / 1$ & & & \\
\hline Raw water & $9.88 \pm 4.10$ & $* * * \mathrm{P}<0.001$ & $* * * \mathrm{P}<0.001$ \\
\hline Sedimentation & $5.39 \pm 2.83$ & - & - \\
\hline Coagulation & $2.99 \pm 1.65$ & $* \mathrm{P}<0.05$ & - \\
\hline
\end{tabular}

of hardness by 1.The samples was homogenized by rapid mixing for 2 minutes at $180 \mathrm{rpm}$. The rest time was 30 minutes. Because, between samples 2 and 3 there were no great differences in the flocculation process, the lower amount of coagulant was used for economic reasons.

Then, from both of, raw samples and each applied treatment, have been distributed three separate vessels with the height of $6 \mathrm{~cm}$ water column, which have been subjected to disinfection with UV using the device Germicide at wavelength of $253.93 \mu \mathrm{m}$, and the UV dose measured in $\mathrm{mJ} /$ $\mathrm{cm}^{2}$ calculated after formula: UV intensity $\mathrm{x}$ exposure time (Leinberger, www.elaguapotable. com/,). Exposure intervals were: 10, 20, 30 minutes.

Bacterial load was determined through spread plate method (Uzma et al., 2015). After each time interval, $1 \mathrm{ml}$ of water was taken with sterile pipettes transferred onto a sterile Petri plate and mixed with $18 \mathrm{ml}$ of agar, incubated for 24 hours at $37^{\circ} \mathrm{C}$ to determine $\mathrm{TNG} / \mathrm{ml}$.

Comparison of the values obtained after sedimentation, coagulation and raw water were done after one-way analysis of variance (ANOVA) followed by parametric test ( $\mathrm{t}$-test), and the values obtained after exposure to UV on variable time by nonparametric test (Kruskal-Wallis). In both situations the results is represented as mean $\pm S D$, and the differences considered significant if $p$ $\leq 0.05$.

\section{Results and Discussion}

The purpose of the research was to find the optimal variant to reduce the bacterial load from an impure surface water, with high turbidity, rich in organic matter using as physical processes - sedimentation, chemical - coagulation, both processes being followed by UV disinfection.
For calculating the optimal dose of coagulant, León-Luque et al., (2016), Farhaoui et al., (2016), take into account more physical and chemical parameters, but especially, the initial $\mathrm{pH}$ of the water for dosing the cationic coagulant, alum.

In this research the dosage of the alum was performed starting from the values obtained at the temporary hardness parameter. Temporary hardness determined in the three experimental variants: raw water, sedimentation, coagulation, it's diminishing extremely significant by coagulation.

Individual values of the temporary hardness of the raw sample (RW): $8.4-15.24^{\circ} \mathrm{G}$, are very close to those obtained in the sedimentation process (SS) $\left(8.2-14.84^{\circ} \mathrm{G}\right)$ (table 1). After coagulation (SC), parameter values are greatly reduced (2.45$5.6^{\circ} \mathrm{G}$ ), fact confirmed by Pernitsky (2003) which indicates that, alum leads to greater consumption of alkalinity than other complex coagulants. From statistical point of view insignificant differences are found between raw water and samples subjected to sedimentation and extremely significant $\left({ }^{* * *} \mathrm{P}<0.001\right)$ after coagulation. Therefore, the best way to reduce temporary hardness is coagulation, relative to sedimentation. The amount of alum used was of $6.4 \mathrm{ml}$ și $12 \mathrm{ml} \mathrm{Al}\left(\mathrm{SO}_{4}\right)_{3} 1 \%(1 \mathrm{ml}$ alum corresponds to $10 \mathrm{mg}$ alum).

In the flocculation process it is extremely important that, water to have good buffering capacity, because of acidic reaction of the coagulant which can lead to a sudden decreases of pH from water (Kawamura, 1996).

Referring strictly to organic matter in the water Ashery et al. (2010), give good values of $\mathrm{pH}$ between 5 and $6 \mathrm{pH}$ units, for the efficient removal of organic matter from water. After the same authors, higher values increase the dose of coagulant. 
Table 2. The values TNG / $\mathrm{ml}$ of water, on raw water samples, samples subjected to sedimentation and those subjected to coagulation

\begin{tabular}{|c|c|c|c|c|c|c|}
\hline$(\mathrm{n})$ & Parameters & $\begin{array}{c}\text { Mean } \pm \mathrm{Sd} \\
\mathrm{TNG} / \mathrm{ml} \\
\end{array}$ & $\begin{array}{c}\text { Min. } \\
\text { TNG/ml }\end{array}$ & Max. TNG/ml & SS & $\mathrm{SC}$ \\
\hline 15 & RW & $6437.4 \pm 2606.1$ & 1780 & 964 & $* * \mathrm{P}<0.01$ & $* * * \mathrm{P}<0.001$ \\
\hline 15 & SS & $4159.2 \pm 300.2$ & 678 & 7460 & - & $* * * \mathrm{P}<0.001$ \\
\hline 15 & $\mathrm{SC}$ & $795.2 \pm 40.9$ & 193 & 2140 & - & - \\
\hline
\end{tabular}

The initial value of $\mathrm{pH}$ in the samples analyzed, have range between 7.35-7.90 unit $\mathrm{pH}(7.73 \pm 0.18$ unit $\mathrm{pH}$ ) but, the results obtained according to the method chosen in this research without increasing the coagulant dose, lead to the same extremely significant decreases $(* * * \mathrm{P}<0.001)$ after coagulation to the parameter CCOMn (table1), but also an extremely significant decrease in $\mathrm{pH}$ (5.71 $\pm 0.31 ; 5.26-6.2$ unit $\mathrm{pH}$ ).

After sedimentation, the amount of organic matter decreases from 19.6-4.31 (raw water) to 9.1-1.27 $\mathrm{mgO}_{2} / \mathrm{l}$, that, on average represents a decrease with approximately $45 \%$. Much lower values it can be noted after coagulation. The organic load is reduced on average by $69.73 \%$ (0.89-5.59 $\left.\mathrm{mgO}_{2} / \mathrm{l}\right)$ compared with initial value (RW) and $55.47 \%$ compared to sedimentation. Of the total number of samples, $86.66 \%$ of the values obtained after coagulation are under $5 \mathrm{mgO}_{2} / \mathrm{l}$, which would correspond with drinking water standards.

By the coagulation process, using alum as the only coagulation agent, a significant elimination of organic matter is achieved, fact confirmed by other authors (Pernitsky, 2003).

Percentage value with that the organic matter was reduced was between 50.1 and $84.55 \%$. Research conducted by Mbaeze et al. (2017), have shown that, by coagulation, organic matter can be reduced by $19-100 \%$. The dosing of the coagulant was performed according to the initial $\mathrm{pH}$ of the water. Daryabeigi et al.(2015) find efficiency of 65\% using $150 \mathrm{mg} / \mathrm{l}$, and Zehra et al., (2009), efficiency of $31 \%$ by adding $80 \mathrm{mg}$ alum/l. The values TNG / ml of water, on raw water samples, samples subjected to sedimentation and those subjected to coagulation.

of the three experimental variants, the coagulation is considered the optimal treatment option in terms of reducing the bacterial load, existing extremely significant differences $\left({ }^{* * *} \mathrm{P}<0.001\right)$ between this variant, raw water and sedimentation (Table 2). This is due to the fact that, particles and microorganisms of interest are subject to electrostatic attraction by a positively charged surface, such as a chemical coagulant, when they are negatively charged in an aqueous medium (Guo, 2005). Reduction of bacterial load is also observed in the case of sedimentation (4159.2 \pm 300.2$)$ compared to raw water (6437.4 \pm 2606.1), the differences being distinctly significant $\left({ }^{* *} \mathrm{P}<0.01\right)$, but, through the sedimentation process, there is no constant reduction of microbial contamination, and in addition, the suspensions from water may contain pathogenic microorganisms (Daryabeigi et al., 2015). After sedimentation TNG/ml water, decreases by approximately $35 \%$ relative to the raw water samples analyzed in terms of bacterial load, and after coagulation with about $87 \%$, values close to other research made on this topic where, the elimination of the bacterial charge through the two processes it was between 32 and $87 \%$ (https://www.safewater.org/, 2017).

Each of the three experimental variants was subjected to UV disinfection at 10, 20, 30 minutes exposure. Exposure of raw water to UV disinfection, indicates that, decreasing $\mathrm{TNG} / \mathrm{ml}$ water is significant depending on the UV exposure period and UV dose $\left(1 \log -3.40 \mathrm{mj} / \mathrm{cm}^{2}\right.$ at 10 minutes, $3.70 \mathrm{mj} / \mathrm{cm}^{2}-20$ minutes, $3.88 \mathrm{mj} / \mathrm{cm}^{2}, 30$ minutes). At 10 minutes the reduction is extremely variable, between $49.33 \%$ and $96.04 \% \mathrm{TNG} / \mathrm{ml}$ water and significant from statistical point of view between 10 and 20 minutes (table 3). One of the possible explanations of the values obtained at 10 minutes exposure is due to the turbidity of the raw 
Table 3. TNG / ml water values after exposure to UV at variable times

\begin{tabular}{|c|c|c|c|c|c|c|c|c|}
\hline \multicolumn{9}{|c|}{ Exposure of raw water to UV disinfection } \\
\hline \multirow{2}{*}{ (n) } & \multirow{2}{*}{ Parameters } & \multirow{2}{*}{ Mean \pm Sd TNG/ml } & \multirow{2}{*}{ Med } & \multirow{2}{*}{$\begin{array}{c}\text { Min } \\
\mathrm{TNG} / \mathrm{ml}\end{array}$} & \multirow{2}{*}{$\begin{array}{c}\text { Max } \\
\text { TNG/ml }\end{array}$} & \multicolumn{3}{|c|}{ RW exposure at: (min.) } \\
\hline & & & & & & 10 & 20 & 30 \\
\hline 15 & RW & $6437.46 \pm 672.9$ & 7250 & 1780 & 9642 & $*$ & $* * *$ & $* * *$ \\
\hline 15 & RW - 10 min. & $925.53 \pm 183.7$ & 69 & 158 & 2373 & - & ns & $* * *$ \\
\hline 15 & RW - 20 min. & $287.33 \pm 78.2$ & 151 & 75 & 975 & - & - & ns \\
\hline 15 & RW - 30 min. & $82.93 \pm 21.1$ & 53 & 4 & 266 & - & - & - \\
\hline \multicolumn{6}{|c|}{$\%$ TNG reduction raw water at UV exposure } & $\begin{array}{r}83.7 \\
\pm 3.6 \\
\end{array}$ & $\begin{array}{l}94.4 \\
\pm 2.0 \\
\end{array}$ & $\begin{array}{l}98.5 \\
\pm 0.3 \\
\end{array}$ \\
\hline \multicolumn{9}{|c|}{ Exposure of SS to UV disinfection } \\
\hline \multirow{2}{*}{$(\mathrm{n})$} & \multirow{2}{*}{ Parameters } & \multirow{2}{*}{$\begin{array}{c}\text { Mean } \pm S d \\
\mathrm{TNG} / \mathrm{ml}\end{array}$} & \multirow{2}{*}{ Med } & \multirow{2}{*}{$\begin{array}{c}\text { Min } \\
\text { TNG/ml }\end{array}$} & \multirow{2}{*}{$\begin{array}{c}\text { Max } \\
\text { TNG/ml }\end{array}$} & \multicolumn{3}{|c|}{ SS exposure at: (min.) } \\
\hline & & & & & & 10 & 20 & 30 \\
\hline 15 & SS & $4159.2 \pm 1860.0$ & 4002 & 678 & 7460 & $* *$ & $* * *$ & $* * *$ \\
\hline 15 & $\mathrm{SS}-10 \mathrm{~min}$. & $92.73 \pm 111.41$ & 49 & 4 & 316 & - & ns & ns \\
\hline 15 & SS -20 min. & $30.73 \pm 32.21$ & 22 & 0 & 87 & - & - & ns \\
\hline 15 & SS $-30 \mathrm{~min}$. & $12.53 \pm 15.42$ & 4 & 0 & 55 & - & - & - \\
\hline \multicolumn{6}{|c|}{$\%$ TNG reduction to different times of exposure to UV } & $\begin{array}{r}95.6 \\
\pm 8.6 \\
\end{array}$ & $\begin{array}{l}98.8 \\
\pm 1.7 \\
\end{array}$ & $\begin{array}{l}99.4 \\
\pm 1.0 \\
\end{array}$ \\
\hline
\end{tabular}

\begin{tabular}{|c|c|c|c|c|c|c|c|c|}
\hline \multicolumn{9}{|c|}{ Exposure of SC to UV disinfection } \\
\hline \multirow{2}{*}{ (n) } & \multirow{2}{*}{ Parameters } & \multirow{2}{*}{$\begin{array}{c}\mathrm{Mean} \pm \mathrm{Sd} \\
\mathrm{TNG} / \mathrm{ml}\end{array}$} & \multirow{2}{*}{ Med } & \multirow{2}{*}{$\begin{array}{c}\text { Min } \\
\mathrm{TNG} / \mathrm{ml}\end{array}$} & \multirow{2}{*}{$\begin{array}{c}\text { Max } \\
\text { TNG/ml }\end{array}$} & \multicolumn{3}{|c|}{ SC exposure at: (min.) } \\
\hline & & & & & & 10 & 20 & 30 \\
\hline 15 & SC & $795.26 \pm 628.49$ & 635 & 193 & 2140 & $* *$ & $* * *$ & $* * *$ \\
\hline 15 & $\mathrm{SC}-10 \mathrm{~min}$. & $17.80 \pm 20.27$ & 8 & 0.0 & 54 & - & ns & ns \\
\hline 15 & SC-20 min. & $6.80 \pm 10.30$ & 3 & 0.0 & 38 & - & - & ns \\
\hline 15 & $\mathrm{SC}-30 \mathrm{~min}$. & $2.20 \pm 4.29$ & 0.0 & 0.0 & 16 & - & - & - \\
\hline \multicolumn{6}{|c|}{$\%$ TNG reduction to different times of exposure to UV } & $\begin{array}{l}96.1 \\
\pm 6.6\end{array}$ & $\begin{array}{l}98.4 \\
\pm 2.7\end{array}$ & $\begin{array}{l}99.6 \\
\pm 0.7\end{array}$ \\
\hline
\end{tabular}
coagulation, (n)- No of samples, ${ }^{* * *}-\mathrm{P}<0.001$; ${ }^{* *}-\mathrm{P}<0.01,{ }^{*}-\mathrm{P}<0.05$; ns- $\mathrm{P}>0.05 ; 10 \mathrm{~min}, 20 \mathrm{~min}, 30 \mathrm{~min}$-exposure time of the samples

water, whose values are extremely high 72.5-211 NTU (116.4 \pm 49.2 Nephelometric Turbidity Units).

In order for UV disinfection to be effective, turbidity must have low values: 0.3 NTU (Edzwald et al., 2009) and after Darling et al. (2003), less than 5 NTU.

At 20 minutes, the percentage values indicates decreasing the $\mathrm{TNG} / \mathrm{ml}$ water, between $68.08 \%$ and $98 \%$, while, at 30 minutes in all samples, diminishing to be possible in percent of 96.36$99.95 \%$ compared with raw water values. Between exposure to 10 minutes and 30 minutes the dispersion indices show an extremely significant reduction of $\mathrm{TNG} / \mathrm{ml}$ water. The differences are insignificant between 20 and 30 minutes, but the values obtained, demonstrates a good remedy of the situation in terms of bacterial load.
Following the sedimentation process, the values of $\mathrm{TNG} / \mathrm{ml}$ water decrease progressively with exposure time, with extremely significant differences $\left({ }^{* * *} \mathrm{P}<0.001\right)$ between water subject only to sedimentation and exposure at 20,30 minutes, where, the value of $\mathrm{TNG} / \mathrm{ml}$ water is reduced in percent by $98.38 \pm 3.36,99.42 \pm 0.85$ and distinctly significant $\left({ }^{* *} \mathrm{P}<0.01\right)$ at 10 minutes, when in percent TNG/ml water is diminished with 95.95 \pm 6.09 (78.65-99.82\%).Extremely significant differences are found in the coagulation between exposure to 20 minutes, respectively 30 minutes. In 9 of the samples, which means $60 \%$, the value of $\mathrm{TNG} / \mathrm{ml}$ water was 0 . At 10 minutes was observed reduction up to disappearance only for a sample, and at 20 minutes in 5 of the samples, turbidity varying between 31 and 4 NTU $6.6 \pm 9.08$ NTU. The extremely low values compared with the initial 
turbidity of raw water after coagulation were also obtained by Alshikh (2007) in the case of samples with moderate and high turbidity.

In terms of the bacterial load, all the samples treated with the cationic coagulant, alum at 30 minutes exposure to UV, may be considered drinking water after L 458/2002, the maximum admissible number being $20 \mathrm{TNG} / \mathrm{ml}$ water. However, besides mesophilic bacteria there are microorganisms resistant to UV-dependent application and the germ group (Hijnen et al., 2006).

\section{Conclusion}

Temporary hardness determined in the three experimental variants: raw water, sedimentation, coagulation, it's diminishing extremely significant by coagulation. After sedimentation, the amount of organic matter decreases but, after coagulation, the values of parameter CCOMn, has extremely significant decreases $\left({ }^{* * *} \mathrm{P}<0.001\right)$ without increasing the coagulant dose. Of simple water treatment processes, coagulation, is the process by which, the bacterial charge is substantially reduced.

In a water with medium, high, degree of impurification, coagulation process is ineffective if is not followed by disinfection step. UV dose influences the decrease in germ count. The highest decrease was observed at the maximum exposure time (30 minutes, $1 . \log 3.88 \mathrm{mj} / \mathrm{cm}^{2}$ ).

Using ultraviolet radiation alone, without being accompanied by other processes such as, sedimentation or coagulation, is not a solution for destroying the microorganisms from a water with high turbidity.

Coagulation followed by UV disinfection can be a way to reduce by up to $99 \%$ the bacterial load, even in the situation where water is contaminated with a lot organic matter.

\section{References}

1. Alshikh O (2007). Parameters affecting coagulation/ flocculation of drinking water under cold temperatures. Electronic Theses and Dissertations.6987. https:// scholar.uwindsor.ca/etd/6987.

2. Ashery AF, Radwan K, and Gar Al-Alm Rashed MI (2010). The effect of $\mathrm{pH}$ control on turbidity and NOM removal in conventional water treatment. Fifteen ${ }^{\text {th }}$ International Water Technology Conference, IWTC 15, Alexandria, Egypt).
3. Baghvand A, Daryabeigi AZ, Mehrdadi N, Karbassi A. (2010). Optimizing Coagulation Process for Low to High Turbidity Waters Using Aluminum and Iron Salts. American Journal of Environmental Sciences 6(5), 442448.

4. Bartram J, Balance R (1996). Water Quality Monitoring - A Practical Guide to the Design and Implementation of Freshwater Quality Studies and Monitoring Programmes, Chaptel 2 Water quality, Published on behalf of United Nations Environment Programme and the World Health Organization, ISBN 0419223207.

5. Betancourt WQ, Rose JB (2004). Drinking water treatment processes for removal of Cryptosporidium and Giardia. Veterinary Parasitology 126, 219-234.

6. Bulson PC, Johnstone DL, Gibbons HL, Funk WH (1984).Removal and inactivation of bacteria during alum treatment of a lake. Applied And Environmental Microbiology, 48(2):425-430.

7. Chevrefils G, Ing B, Caron É (2006). UV Dose Required to Achieve Incremental Log Inactivation of Bacteria, Protozoa and Viruses, IUVA News, 8(1):38-45.

8. Darling, S. and Lemley A.T (2003). Disinfection of Drinking Water using UV light, http://www.cce.cornell.edu/.

9. Daryabeigi ZA, Hoveidi H (2015). Comparing Aluminium Sulfate and Poly-Aluminium Chloride (PAC) Performance in Turbidity Removal from Synthetic Water, Journal of Applied Biotechnology Reports, Volume 2, Issue 3: 287292.

10. Dawson S (2018). Water: the forgotten nutrient in pigs, https://www.agric.wa.gov.au/.

11. Edzwald KJ, Dee PE, Kaminski GS (2009). A practical method for water plants to select coagulant dosing. Journal of the New England Water Works Association, vol.123 (1) pp.15-31.

12. Farhaoui M, Hasnaoui L, Derraz M (2016). Optimization of Drinking Water Treatment Process by Modeling the Aluminum Sulfate Dose. British Journal of Applied Science \& Technology 17(1): 1-14, 2016, Article no.BJAST.26840.

13. Farrell C, Hassard F, Jefferson B, Leziart T, Nocker A, Jarvis $P$ (2018). Turbidity composition and the relationship with microbial attachment and UV inactivation efficacy, Science of The Total Environment, Vol. 624, pp. 638-647.

14. Gray NF (2014). Microbiology of Waterborne Diseases (Second Edition), Chapter Thirty - Pathogen Control in Drinking Water, pg 537-569, Academic Press.

15. Gullian M, Espinosa-Faller FJ, Núñez A, López-Barahona N (2012). Effect of turbidity on the ultraviolet disinfection performance in recirculating aquaculture systems with low water exchange, Aquaculture Research 43(4):595-606, https://doi.org/10.1111/j.1365-2109.2011.02866.x.

16. Guo L (2005). An investigation of UV disinfection performance under the influence of turbidity \& particulates for drinking water applications, thesis presented to the University of Waterloo.

17. Gwyn N, Douglas I, Beaty J, Elliott J (2014). Coagulation Optimization: Improving the "heart" of the water treatment . Canadian National Conference on drinking 
water treatment technology and processes www.cwwa. ca/pdf_files/.

18. Hijnen WAM, Beerendonk EF, Medema GJ (2006). Inactivation credit of UV radiation for viruses, bacteria and protozoan(oo)cysts in water: A review $\bullet$, Water Research, 40: 3-22.

19. Johnson KM, Kumar MR, Ponmurugan P, Gananamangai BM (2010). Ultraviolet radiation and its germicidal effect in drinking water purification, Journal of Phytology, 5:1219.

20. Jowa T, Mguni LL(2015).Treatment of Low Turbidity Water Using Poly-Aluminium Chloride (PAC) and Recycled Sludge: Case study Chinhoyi. Zimbabwe Journal of Science \& Technology, vol. 10, pp 101-108.

21. Kawamura S, (1996). Optimization of Basic Water Treatment Processes - Design and Operation: Coagulation and Flocculation. Journal water Supply Research and Technology, AQUA 45(1), 35-47.

22. Kimura M, Matsui $Y$, Kondo K, Ishikawa TB, Matsushita T, Shirasaki N, (2013). Minimizing Residual Aluminum Concentration in Treated Water by Tailoring Properties of Polyaluminum Coagulants, Water Research 47(6):20752084.

23. Lanciné GD, Bamory $\mathrm{K}$, Ligban $\mathrm{R}$, Jean-Luc $\mathrm{S}$, Batiot $\mathrm{C}$, Biemi J(2008). Coagulation-Flocculation Treatment of a Tropical Surface Water with Alum for Dissolved Organic Matter (DOM) Removal: Influence of Alum Dose and pH Adjustment, J. Int. Environmental Application \& Science, Vol. 3 (4): 247-257.

24. Leinberger J. Disinfection of Drinking Water with Ultraviolet Light http://www.elaguapotable.com/.

25. León-Luque AJ, Barajas CL, Peña-Guzmán CA, (2016). Determination of the Optimal Dosage of Aluminum Sulfate in the Coagulation-Flocculation Process Using an Artificial Neural Network. International Journal of Environmental Science and Development, Vol. 7, No. 5:346-350.

26. Liu WJ, Zhang, YJ (2006). Effects of UV intensity and water turbidity on microbial indicator inactivation. J Environ Sci, 18(4):650-3.

27. Man C (1986). Practical, Zoo-hygiene, for the students' use. Tipo Agronomia, pp. 92-104.

28. Man C (1989). Water - animal health and production. Ed. Ceres, Bucureşti .

29. Mann AG, Tam CC, Higgins CD, Rodrigues LC (2007). The association between drinking water turbidity and gastrointestinal illness: a systematic review, BMC Public Health, vol.7:256 doi:10.1186/1471-2458-7-256/.

30. Matilainen A, Vepsäläinen M, Sillanpää M (2010). Natural organic matter removal by coagulation during drinking water treatment:A review. Advances in Colloid and Interface Science 159, 189-197.

31. Matilainen A, Lindqvist N, Tuhkanen T (2005). Comparison of the effiency of aluminium and ferric sulphate in the removal of natural organic matter during drinking water treatment process. Environ Technol. Vol. 26(8), pg. 867875.

32. Mbaeze MC, Agbazue VE, Orjioke NM (2017). Comparative Assessment of Performance of Aluminium Sulphate (Alum) and Ferrous Sulphate as Coagulants in Water Treatment-Modern Chemistry \& Applications, 1-14, DOI: 10.4172/2329-6798.1000233.

33. Moşneag SC, Popescu V (2011) Coagulation-flocculation process. A XI -a Conferinţă Naţională Multidisciplinară - cu participare internatională, "Profesorul Dorin Pavelfondatoprul hidroenergeticii românești” Sebeș, p 2032010.

34. Mouna J, Noureddine A (2013).Coagulation treatment by $\mathrm{Al}_{2}\left(\mathrm{SO}_{4}\right)_{3}$ and residual al determination in medjerda water dam (Tunisia), Journal de la Société Chimique de Tunisie, vol. 15: 175-181.

35. Pernitsky DJ, Edzwald JK (2006). Selection of alum and Polyaluminium coagulants: principles and applications. Journal of Water Supply: Research and Technology AQUA,55(2):121-141.

36. Pernitsky DJ, (2003). Coagulation 101, Associated Engineering, Calgary, Alberta, https://www.scribd.com/ document/233945562/Coagulation.

37. Rod Davis (2016). Feedlot design and construction, 5. Water quality, https://www.mla.com.au/.

38. Sahu OP; Chaudhari PK (2013). Review on Chemical treatment of Industrial Waste Water. J. Appl. Sci. Environ. Manage,Vol. 17 (2) 241-257.

39. Stanfield G, Lechevallier M, Snozzi M (2003). Treatment efficiendy. In: Assessing microbial safety of drinking water: improving approaches and methods. eds Dufour A, Snozzi M, Koster W, et al.), IWA Publishing, pp. 159-178.

40. Uzma H, Abu Bakar M, Jahngeer A, Ikram-Ul-Haq (2015). Determination of Microbial load of Drinking Water from different areas of Lahore, Biologia (Pakistan), vol.61 (1) pg. 151-156.

41. Zahra F, Panahi R, Mokhtarani B (2017). Timecourse study of coagulation-flocculation process using aluminum sulfate, Water Conservation and Management , 1(2):0709.

42. Zehra Y, Hatice I, Seydioglu G, Uyak V (2009). Enhanced coagulation of disinfection by-products precursors in Porsuk water resource, Eskisehir, International Scholarly and Scientific Research \& Innovation, pp.175-178.

43. Zyara AM, Torvinen E, Veijalainen AM, Heinonen-Tanski, $\mathrm{H}$ (2016).The Effect of UV and Combined Chlorine/UV Treatment on Coliphages in Drinking Water Disinfection, Water 8,pp 1-9.

44. Conventional Water Treatment: Coagulation and Filtration https://www.safewater.org/fact-sheets-1/2017/1/23/ conventional-water-treatment.

45. Climatological characteristics of Cluj Napoca https:// www.vremea.ro/gt/clima-cluj-napoca/.

46. Quide of collecting samples of water http://www.dspcluj. ro/HTML/laborator/Ghid\%20prelevare\%20apa.pdf. 